\title{
THE REVIVAL TEXTBOOKS FROM THE OLD-FASHIONED COLLECTION OF THE COMMUNITY CENTRE „NADEJDA-1869”
}

\author{
Pavlina Vladeva \\ pvladeva@gmail.com
}

Club in domestic culture "Nadezda", Community centre "Nadejda -1869", Veliko Tarnovo, Bulgaria

\begin{abstract}
The subject of the study was 45 textbooks, published from 1835 to 1875 were preserved in the old-fashioned collection of the centre community "Nadejda-1869". Their authors are 17 teachers who wrote, translated and published first Bulgarian textbooks in the XIX-th century. They are journalists writing the first newspapers and magazines. They lead the struggle for new Bulgarian education, church independence and political freedom. They reform the education and the place of the cell, they build the secular.

They are innovators, they introduce the study of new school subjects and languages according to the needs of the time. The text presents first textbooks in Bulgarian language, readings and grammar, arithmetics, geometry and physics. They are textbooks on history, geography, textbooks of natural history. Were preserved textbooks of logic, textbooks of moral and textbooks and dictionaries in French and German, sacred Orthodox catechisms. The article presents the history and development of the curriculum in Bulgarian schools in the XIX C.. ${ }^{\text {I }}$

Keywords: Old-Fashioned Collection; Centre Community "Nadejda-1869"; Teachers; Authors; First Bulgarian Textbooks in the XIX-th; New Bulgarian Secular Education; New School Subjects and Languages; First Textbooks in Bulgarian Language; Readings; Grammar; Arithmetics; Geometry and Physics; History Textbooks; Geography; Textbooks and Dictionaries in French and German
\end{abstract}

\section{ВЪЗРОЖАЕНСКИ УЧЕБНИЦИ ОТ СТАРОПЕЧАТНАТА СБИРКА НА ЧИТААИЩЕ „НААЕЖАА-1869"}

\author{
Павлина В^алева \\ КАуб по битова култура „НалежАа", \\ Читалище „НалежАа 1869", Велико Търново, България \\ Резюме: Обект на изследването са 45 учебника, издалени от \\ 1835 г. Ао 1875 г., съхранявани в старопечатната сбирка на читалище \\ "НацежАа-1869". Техните автори са 17 учители, които пишат, \\ превежАат и издават пьрвите бъмгарски учебници през XIX век. Те са
}

' All images in the paper are taken from the textbooks listed in Application 1. 
журналисти и пишат пьрвите вестници и списания. Те повежАат борбата за новобългарска просвета, църковна независимост и политическа свобола. Те рефоормират образованието и на мястото на килийното, изгражАат светското. Те са новатори, въвежАат нови учебни Аисциплини, езици в крак с потребностите на новото време. $B$ изложението са представени пьрвите учебници по български език, читанки, граматики, аритметики, геометрии, ффизики. Има учебници по история, география, естествена история. Запазени са ^огики, учебници по нравоучение, учебници и речници по фрренски и немски език, свещени православни катехизиси. Статията представя историята

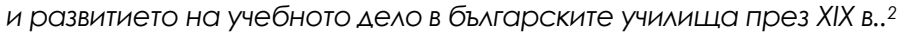

КАючови Ауми: Старопечатна сбирка, читалище „НалежАа1869", учители, автори, Първи български учебници от XIX век, новобългарско светско образование, нови учебни Аисциплини и езици, пьрви учебници по български език, читанки, граматики, аритметики, геометрии и фоизики, истории, географрии, учебници и речници по фрренски и немски език.

\section{Въведение}

На 8 юни 1869 г. преАи век и половина 32 рололюбиви търновци поставят началото на читалище „НалежАа". „Неговата це^ била и си остава: умственото и нравствено развитие на неговите членове - въобще на гражАаните и възбужАане на обществения живот" (Yankov, 1939: р. 139). Аимитьр х. Павли Иванов е избран за председател. Чрез щелри Аарения търновските гражАани организират читалищна библиотека. Учителката Евгения Кисимова подарява 368 книги. Голям Аарител е и търновският учитеА Кънчо Кесаров.

В резултат на икономическия подем на някоИ възрожАенски градове през пьрвата половина на XIX в. започва откриването на нов тип училища елино-български и класни, които $А$ заменят килийните училища. Необхолимостта от новобългарско образование поражАа откриването на светски училища по българските земи. „Подготвени учители по взаимоучителната метода се появяват слеА откриването на Габровското училище през 1835 г. Новото училище изиграва ролята на школа за полготовката по тази метола и представлява нов етап в развитието на българската просвета - новобьлгарско образование"

2 Всички изображения в статията са взети от учебници в Приложение 1. 
(Lazarov, 2016: р. 222). От 1824 Ао 1876 г. са изАалени 434 български учебници по различни учебни Аисциплини.

Ао Освобожлението излизат 76 размични буквара. В читалищната библиотека се съхраняват 2 буквара, на Сава Ралулов от 1866 г. И на Аимитьр Благоев от 1874 г. Анес в старопечатния библиотечен фронА на читалище „НалежАа-1869” се намира безценно културно наслеАство, завещано ни от нашите предци. Запазени са 12 рькописа от XV-XIX век, 413 старопечатни книги и учебници от перио $\Delta$ a (1816-1878), 18 заглавия на вестници и 15 заглавия на списания от XIX в..

\section{Учители - автори на първите възрожАенски учебници}

През XIX в. порали нужАата от учебна митература за новите к^асни учи^ища много учители започват Аа превежАат и приспособяват руски, гръцки и срьбски учебници за тази цел. Те съставят и пишат нови учебници т. е. стават учебникари. По този начин се офрормя специално учебникарско направление в книгоиздаването, в което са съсредоточени основните усилия на възрожленската интелигенция. Учебниците се печатат в чужбина, тъй като по това време по българските земи няма печатници. Обект на нашето изследване са 17 възрожленски учители и написаните от тях 45 учебника. Те са издалени за периол от 40 години (1835-1875) и са ценна част от старопечатната сбирка на библиотеката при читалище „НалежАа-1869". Ще проследим жизнения, профресионалния и обществен пьт на тези вьзрожАенски учители. Те са еАни от най-образованите българи на XIX в., поставили основите на светското образование по българските земи. Аейцитепросветители, остави^и ни тези книжовни съкровища са: Неофит Рилски, Емануил ВаскиАович, Христолул Сичан-Николов, Сава Ралулов, Никола Михайловски, Иван Богоров, Иван Момчилов, Теолор Хрулев, А-р Васил Берон, Христо Г. Аанов, Йоаким Груев, Кънчо Кесаров, Тодор Шишков, Нестор Марков, Аимитьр Благоев, Христо Ваклидов, Иван Гюзелев.

Неофит Рияски (1793-1881) е роден в Банско. Той е забележителен българин: монах и учител, художник и автор на учебници. Наречен е от Константин Иречек „патриарх на българските учители и книжовници". Учи в Рилския манастир. Продьлжава 
образованието си в Букурещ и там се запознава с взаимоучителната метола. През 1835 г. в Габрово е открито взаимно училище, което се преврьща в основно българско средище за полготовка по взаимоучителната метола. Поставено е началото на новобългарското образование. В училището започва да преполава Неофит Рилски. Той превежАа на български език таблиците, по които се води обучението. Написва и пьрвите учебници и „Бьлгарска граматика“, за да може $\Delta а$ се унифрицира и систематизира новобългарския книжовен език. Той е пьрвият теоретик на новобългарското просветно Авижение.

Емануия Васкидович (1795-1875) е роден в Мелник. Той е просветител, книжовник, преводач, общественик, дарител. Учи гимназия на остров Хиос. Там се запознава с модерните за времето си грьцки светски училища. Завършва Княжеската (Бейска) акалемия в Букурещ. През 1815 г. в Свищов се открива пьрвото Елино-българско училище, което е пьрвото светско училище по българските земи. Емануил ВаскиАович поканен Аа го оглави и работи Ао 1845 г. ВьвежАа в него взаимоучителната метола на обучение и предметите граматика, аритметика и география. През периола (1845-1854) е учител в Плевен. През 1849-1850 г. съзАава пьрвото светско училище в граАа, Анес Гимназия с преполаване на чужди езици. През периола (1854-1863) е отново учител в Свищов. Емануил ВаскиАович е инициатор и член на рьководството на пьрвото българско читалище „Еленка и Кирил Аврамови", открито в Свищов 1856 г. Богати свищовлии Ааряват 37409 гроша. Емануил ВаскиАович поАарява 800 книги от мичната си библиотека на библиотечния фонн на читалището. Това е най-голямото Аарение на книги през този периол по българските земи. Повечето книги са изАалени 1815 г., и са на гръцки, сръбски, руски, фрренски и български език. Емануил ВаскиАович е участник в борбата за цьрковна независимост.

\section{Христодул Костович Сичан-Николов (1808-}

1889) е ролен в Самоков. Учи в Рилския манастир, кьАето става монах. Прольлжава образованието си в Австрия. Учителства в Мелник, Свищов и Габрово; редактор е на сп. „Зорница“ в ЦариграА и участва в превода на Библията на новобългарски език.

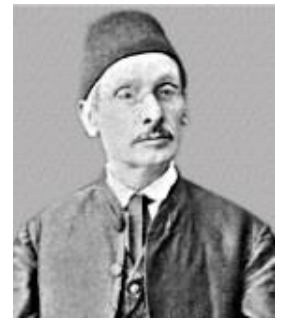




\section{Сава Ралулов (1817-1887) е български учител, писател и} просветен Аеец, роден в Панагюрище като Стойно Ралулов. Учи в Панагюрище и ПазарАжик. Прольлжава учението си в Хилендарския манастир, кьлето е рькоположен за дякон с името Сава. Учи в грьцко училище в Смирна (Измир) (1835-1840) и (1843-1846). Завьршва образованието си в Ришельовския мицей в Олеса (1849-1853). Бил е учител в Панагюрище в еАно от пьрвите класни училища (1841-1842) и (1847-1848). От 1853 г. АО 1858 г. е учител в Основното училище в БолграА ( въвежАа българския език в обучението. Сава РаАулов е елин от основателите на Българското книжовно Аружество БКА (АНес БАН) 1869г. в Браила. Завещава цялото си имущество и 6000 златни фрранка за образованието на ученолюбиви панагюрски деца.

Никола Михайловски (1818-1892) е роден в Елена, кьлето учи в ки^ийно учи^ище. Би^ е еАин от най-образованите българи за своето време. Той е просветен Аеец и учител, автор на учебници, съдия и законодател, журналист и поет, писател и преводач. Благодарение на брат си И^арион Макариополски завьршва гимназия в Атина. Той еАин от първите българи, получили висше образование в Русия. Завършва Московския университет, Аоктор е на фрилософрските науки. Учителства в Елена, Търново, Сливен. През 1863 г. е назначен за управител на търновските училища. „Големи са заслугите му за рефрормирането на учи^ищата в Търново.

Прави нова организация в главното училище като се старае $\Delta$ a отхвърли старите методи на обучение. Курсьт на обучение се сьстои от 5 к^аса с опрелелена програма за всеки клас. ВъвежАа нови предмети: психология, ^огика, реторика и Аруги. Преподава старославянски и новобългарски в съвременната му говорима форма, противопоставяйки се на грькоманите и фанариотския Аух в града. Никола Михайловски е ралетел за чист български език като теоретик на Търновската правописна школа, поААьржаща етимологичния правопис" (Vladeva, 2010: р. 399). Пише статии, превежАа от грьцки и руски език. Високо ерудиран, през 1877 г. е избран за председател на Търновския губернски съА, Аепутат е в Учредителното събрание 1879 г. „Бил член на Върховния касационен съА, 
полпредседател на Аьржавния съвет, народен представител, директор на Пьрва гимназия в Софрия, преподавател по старогрьцки език и Аитература в СУ "Св. КАимент ОхриАСки", член на кодифрикационната комисия. Почетен член на БКА от 1884 г." (Vladeva, 2010: р. 400).

Иван Богоров (1818-1892) е ролен в Карлово. През 1882 г. той пише за себе си: „лекар, ^юбослов, пьрви вестникар, наролен представител". Получава високо образование за своето време. Учи във Велика наролна школа на вселенската патриаршия в Куручешме Цариграл. Продьлжава в Ришельовския лицей в ОАеса (1840-1843). В Аайпциг учи химия (1840-1843). В Париж (1855-1858) следва меАицина. Наричан е „баща на българския вестник". ИзАава в Аайпциг през 1846 г. пьрвия вестник „Български орел” от който излизат 3 броя. Основател е на "Цариградски вестник". През 1868 г. изАава самостоятелно пьрвия български пътепис „Няколко Аена разхолка по българските места". По време на Руско-турската война (1877-1878) е преводач. Почетен член е на БКА (АН. БАН) от 1884 г. Иван Богоров е еАин от строителите на новобългарския книжовен език. През целия си живот той се бори с гръцкото образование в българските гралове. Поставя книжовния език върху съвременна народна основа. Предпазва го от чужАи влияния: гърцизми, цьрковнославянизми и русизми с цел запазване на народностния му облик. Има принос при изгражАането на общонароден писмен език.

Иван Момчилов (1819-1869) е роден в ЕАена. В родния си граА учи при Андрей Робовски. Продължава образованието си при грьцкия пелагог и орилософ Теофилос Каирис на остров Андрос. ЕАна година следва в ОАеската Ауховна семинария (1842-1843.) Основава през 1844 г. в Елена пьрвото класно училище, наречено „Ааскалоливница", от неговият ученик П. Р. САавейков, тъй като много негови възпитаници стават учители и се превръща в своеобразен учителски институт за своето време. Училището е структурирано по руски образец.

Ив. Момчилов изработва нагледни таблици по различните предмети. Преполава на чист български език. Снаблява училището с географрски карти и атласи от ОАеса. Иван Момчи^ов поставя основите на българското класно училище в Горна Оряховица през 1859 г. и 
учителства АО 1864 г. От 1865 г. се отАава на книжовна Аейност. В Търново през 1869 г. Иван Момчилов отваря „Книгопродавница Момчилов и сьдружие", наречена от П. Р. САавейков „книжовно Аружество”.

Теодор Хрулев (1821-1865) е роден в Аясковец. Той е просветител, писател, преводач, борец за независима българска цьрква. Бил е с баща си гралинар в Сьрбия. В Свищов е прислужник в училището на Христаки Павлович. По-кьсно става учител. Бори се с гърчеенето на българите и политиката на грьцките влалици за асимилиране на българската цьрква. Наклеветен е прел турските власти, че е получил от сьгражАанина си Павел КалянАжи санАьк с руски книги и, че е „Аушманин на султана". През 1864 г. турският сьА в Русе го осъжАа за революционна Аейност на заточение в Аиарбекир. Принулен да върви пеша, Толор Хрулев се разболява и умира на 30 януари 1865 г.

\section{Котленецьт А-р Васил Берон (1824-1909) оставя} трайна Аиря в обществения и културно-просветния живот на Търново, слеА като свързва живота си с Мария Кисимова и нейната виАна фамилия. А-р Васи^ Берон учи в Котел при Райно Попович. Благодарение на вуйчо си А-р Петьр Берон учи в Плоещ, Крайова, Букурещ и

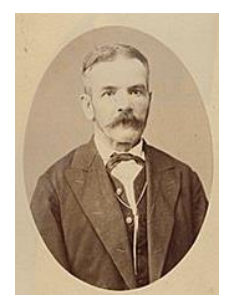
овлаАява румънски и френски език. Усвоява гръцки език във Велика народна школа на вселенската патриаршия в Куручешме - ЦариграА. Завьршва Ришельовския мицей в ОАеса 1846 г. СлеАва меАицина в Мюнхен и Вюрцбург. През 1852 г. получава званието Аоктор по медицина, хирургия и акушерство. Специализира в най-известните болници във Виена, Берлин и Париж. В Букурещ работи като ^екар. По време на Кримската война (1853-1858) е Аоброволен военен лекар кьм руската армия. А-р Васи^ Берон е първият Аип^омиран български ^екар, който работа в поробеното отечество. Установява се в Търново, започва лекарската си практика, открива пьрвата аптека в грала. През периола (1856-1864) работи безвьзмезАно като управител на гралските училища и председател на черковно-училищната община. Берон налага българския език в училищата и усъвьршенства програмите. Вьвежла преполаването в клас на алгебра, геометрия и фризика. 
През периола (1864-1868) А-р Васил Берон е миректор и учител по естествени науки в първата българска гимназия в БолграА (Южна Бесарабия) Анес в (Украйна). „Преработва учебните програми, като вкАючва 14 учебни Аисциплини. Изучават се 7 езика: румънски (който е офрициален), български (за пьрви пьт въвежла изучаването му), руски, фрренски, немски, славянски и латински. Преподава се история математика, фризика, естествени Аисциплини, космографрия агрономия, рисуване. Въвежла кабинетната система на обучение. Укрепва училищната печатница, в която се отпечатват учебници и учебни пособия" (Vladeva, 2016: рр. 251-252). Той е еАин от основателите на БКА (Анес БАН). От 1872 г. Ао 1900 г. В. Берон работи в Търново като лекар. Избран е в ръководството на училищното и черковното настоятелство. Слел Освобожлението е бил кмет, предселател на Окръжния съвет в Търново. На 18 март 1979 г. с активното участие на А-р Васи^ Берон се основава пьрвото археологическо дружество в България. През 1880 г. е назначен за първи директор на Мъжка гимназия „Св. Кирил”.

\section{Основателят на книгоизАаването в България} Христо Груев Аанов (1828-1911) е роден в КАисура. Учи в местното килийно училище, и в кАасното училище на Сава Ралулов в Панагюрище. В Копривщица продьлжава образованието си при Найлен Геров и Йоаким Груев. Бил е педагог Аевет голини. НужАата от

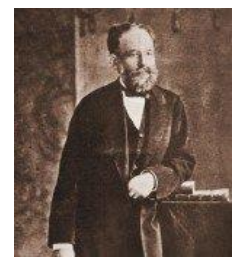
учебна и хуложествена митература на български език го принужАава $\Delta а$ се заеме с издателска дейност. През 1855 г. е отпечатано в Белграл календарче, "Староп^анинче“ за 1856г. С него започва организираното книгоиздаване в България. От 1862 г., Аружеството работи пол фрормата на „Книгоиздателство Хр. Г. Аанов и с-ие“, с клонове в Русе и Велес (1867), Софрия и Аом (1880). Печатат се главно учебници и учебни помагала. А^манахът „Аетоструй” е пьрвото българско списание за Аома. Голям е приносьт на Христо Аанов за т. нар. изАателскоинфоормационна библиографияя в Бьлгария. През 1882 г. Аанов е народен представител в Областното събрание на Източна Румелия. Кмет е на ПловАив (1897-1899). 
Йоаким Груев (1828-1912) е просветител, учител и преводач, автор на учебници. Учи в родния си грал Копривщица при Неодит Рилски. На педагогическото поприще работи 20 години в Копривщица и в П^овАивското кАасно българско училище. Негови възпитаници са Тодор Каблешков, Иван Вазов, Константин

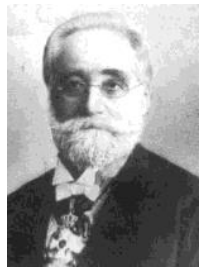
Стоилов. От 1884 г. е член на БКА, (Анес БАН). СлеА СъеАинението е помощник-комисар в Южна Бьлгария. През 1858 г. преАлага $\Delta а$ се празнува 24 май - деня на Кири^ и Метолий като празник на българските ученици.

Кънчо Кесаров (Сахатчиолу) (1832-1875) е ролен в Габрово. Бил е учител в Търново (1851-1852), (1869-1870) и (1873-1877). Преполава в класното училище при цьрквата „Св. Никола” и е еАин от Ааскалите, въвели класното образование в града.

Тодор Шишков (1833-1896) е роден в Търново. Завьршва история в Колеж Аьо Франс при Сорбоната в Париж (1861-1865) с полкрепата на А-р Петьр Берон. През 1866 г. Шишков слуша лекции вьв Фи^ософрския фракултет на Пражкия университет, като отново е

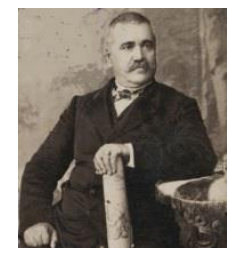
стипендиант на А-р Петьр Берон. През 1870 г. Тодор Шишков е избран за председател на настоятелството на читалище „НаАежАа". „СпореА него читалището е призвано $А$ АопьАва училището. Затова като главен учитеА на търновските училища изявява Аиректно своите претенции Аа рьковоАи Аейността на читалището" (Panayotova and Bachvarova, 2009: р. 15). Бил е учител в Търново през (1868-1871) и (1874-1877). От 1871г. Ао 1873 г. е Аиректор на българското училище в Цариград. Сьтрудничи на "Цариградски вестник“, „Български книжици“, „България“, „Аунавски лебел", „Време", „Македония", „Право", "Турция", „Читалище“, "Зорница". Статиите му са свързани с проблемите на българския правопис, училищното образование и др. През 1873 г. Тодор Шишков открива частно училище с пансион, в което се изучава „тьрговско учение с Аип^ографрия, аритметика, география и др." (Draganova and Dimitrov, 1982: р. 213). СлеА ОсвобожАението Тодор Шишков е прокурор във Варна и Шумен и председател на Свищовския окръжен съА. 
Нестор Марков (1836-1916) е роден в село Криво поле, Хасковско. Той е просветен меец и общественик, реорорматор и книжовник. Учи^ е при Йоаким Груев в П^ов иив. Бил е педагог 40 голини в Харманли, Хасково, Плевен, Габрово. Преподавал е математика, турски и фрренски език. В Плевен през 1869 г. съзАава НЧ

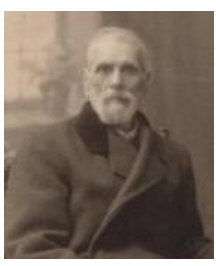
"Съгласие-1869" и театрална група. По време на Руско-турската война (1879-1882) е преволач. СлеА Освобожлението е бил окръжен управител в Стара Загора (1879-1882), в Търново (1882-1884), в Русе (1884-1886), във Варна и Пловлив (1901-1903). Нестор Марков е народен представител в III ВНС в Търново и в XII OHC.

Аимитър Николов Благоев (1840-1875) е ролен в Самоков. Учи в Олеса в Херсонската духовна семинария. Завършва Ауховната акалемия в Киев 1860 г. Бил е учител в Харков, Комрат - Бесарабия. Заврьща се в Бъ^гария слеА 1881 г. Учител е в П^овАив и е Аиректор на ПловАивската гимназия. Преподава: закон божи, цьрковна и всеобща история и педагогика. Благодарение на неговата дейност педагогиката е въведена като специален предмет в тази гимназия. П^овлив става активен центьр за обмен на началното обучение, чрез въвежлането на звучната метола и класно-урочната система за организация на обучението. Най-големи заслуги Аимитьр Благоев има в методиката за обучение по четене и писане. Неговата дейност оказва влияние в развитието на българската метолическа мисьл. ПревежАа от руски език.

Христо Аочев ВаклиАов (ЧерновежАов) (1841-1891) е роАен в Казан^ък. Той е учител, преводач и редактор, книжовник. Пьрвоначално учи в родния си грал. Завършва Френски католически колеж в ЦариграА в кв. Бабек. Учи печатарски занаят в ОАрин и Цариграл. Би^ е учите^ и читалищен деец в Стара Загора. Униат е от 1861. Релактор на в. „България" (1859-1862). През 1861 г. Христо ВаклиАов е редактор на "Цариградски вестник". СлеА Освобожлението заема различни Аьржавни служби. Окръжен управител е в Стара Загора, Пазарлжик, Сливен и Бургас, инспектор в Министерството на фонансите. Сьтрудничи на сп. „Български книжици" 1858 г. и на в. „България" (18591860). 


\section{Иван Гюзелев (1844-1916) е роден в Габрово,}

там учи основно образование. През периола (18601871) завършва Херсонската Ауховна семинария в Одеса и се дип^омира се във Физико-математическия факултет на Новорусийския университет. В Априловската гимназия в Габрово (1870-1877)

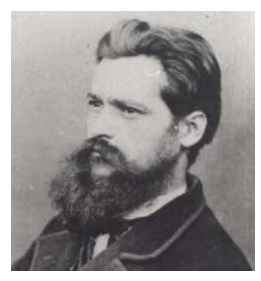
преполава фризика и математика. Той е елин от пьрвите преподаватели по ффизика с висше образование и въвежда изучаването на този предмет в Бьлгария. Оборудва с уреди от Виена пьрвия кабинет по физика, в който има телеграфен апарат.Той е елин от съзАателите на пьрвото читалище и театрална група в Габрово. СлеА потушаването на Априлското вьстание заедно с габровските учители лежи в Търновския затвор. В Учредителното събрание Иван Гюзелев през 1879 г. е народен представител. Аепутат е в във || ВНС, І ОНС, ॥ ОНС. Би^ е министьр на Народното просвещение през 1880 г. Прьв помощник на профр. Марин $\triangle$ ринов по реорганизацията на учебната мрежа в страната. Председател е на Върховната сметна палата от 1880-1894 г. От 1869 г. е

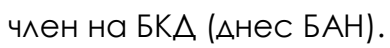

\section{3. ВЪЗРОЖАЕНСКИ УЧЕБНИЦИ ОТ ХІХ}

Неофит Рилски написва пьрвите учебници и „Бьлгарска граматика", за $\Delta а$ може $\Delta a$ се унифицира и систематизира новобьлгарския книжовен език. Той е пьрвият теоретик на новобългарското просветно Авижение. В читалищната библиотека се пази най-старият учебник от XIX век - пьрвата граматика, в която се вижАа влиянието на цьрковнославянския език. Отпечатана е в тогавашната столица на Срьбското княжество граА Крагуевац.

Неофит Римски - Болгарская граматика, Крагуевац, Княжеско-сербска типографрия, 1835, 211 с.

Емануия Васкилович е написал 15 учебника и книги и еАна граматика на старогрьцки език. ПревежАа учебници на Фенелон, останали в рькопис. В библиотеката на читалище „НалежАа-1869" се пази

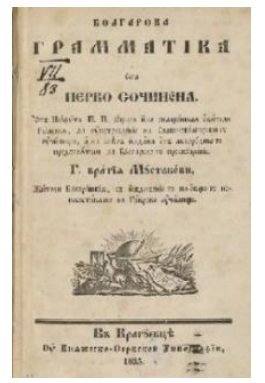


книга за възпитанието на Аецата, подарена от виАната търновка Евгения Кисимова.

ВаскиАович, Емануим - Аетинско притавление или различни нравствени поучения и нравоучителни истории, ЦариграА, типографоия Ц. Вестник, $1852,136 \mathrm{c}$.

Христодул Костович Сичан-Николов изАава енциклопеАичния сборник "Мясецослов" 1840 г. и учебниците „Бьлгарска аритметика" (1845) и „Граматика или буквеница словенска" (1858), която Анес се пази в читалищната библиотека.

Сичан-Николов, Х. - Граматика или буквеница словенска, ЦариграА Галата, книгопечатница наА. Цанков и Б. Мирков, 1858, 168 с.

Сава Ралулов съставя и превежла 18 учебника и учебни помагала от грьцки, руски и френски език. В старопечатния библиотечен фонд се съхраняват 5 учебника, написани или преведени от Сава Ралулов: 1 буквар, 2 граматики, 1 учебник по български език и 1 учебник по нравоучение.

Ралулов Сава - Учебник за българский язык, преведен е преработен от полобен русский учебник", БолграА, печатница на Българското централно училище, 1863, 150 с.

Ранулов Сава - Българский буквар, Олеса, типография на П.Францова, 1866, 32 с. Волени са бележки пол буквите как се произнасят.

Ралулов Сава - Начална граматика за изучения на българский язик. Книжка І, БолграА, печатница на Централно училище, 1870, 116 с.

Ралулов Сава - Нравоучение за децата (от Аьо Пренс Аьомон) (превол) 3 изА., БолграА, печатница Централно училище, 1871, 150 с.

Ралулов Сава - Начална граматика за изучение на българский язик по начин практически. Книжка І, 2 изА., БолграА, печатница Централно училище, 1873, 119 с.

Никола Михайловски е написал учебници по български език и история. В старопечатния библиотечен оронА се съхраняват 4 учебника от Никола Михайловски:

Михайловски, Никола, С. - Очерки из историята и народните сказания (Аревняя история ). Виена, типографоия на ^. Сомер, 1865, 367 с.

Михайловски, Никола, С. - Малка българска читанка, Виена, печ. на . Сомер, 1866, 70 c. 
Михайловски, Никола, С. - Мальк български писмовник или образци за различни писма, Русчук, печ. на Аунавската област, 1868, 64 с.

Михайловски, Никола, С. - РъковоАство Към всеобщата история. Състави^ А. И^овайский, Прев. Търново, Книгопродавница Момчилов и сие, 1873, 338 c.

Иван Богоров е автор на различни учебници и речници по френски език. Тези речници са еАни от пьрвите, от които се нужАаят учениците при чужАоезиковото обучение. Учил в чужбина, получи^ високо образование, Иван Богоров много добре знае, че влалеенето на чужАи езици е важно за търговията, образованието, науката и културата. В предисловието към пьрвото издание на българо-фрренския речник от 1871 г. Иван Богоров обосновава значението на оренския език. През ХІХ век фрренският език е Аипломатическият език на царете, говори се навсякъАе по света, и който го владее има белег на благородство. Чрез

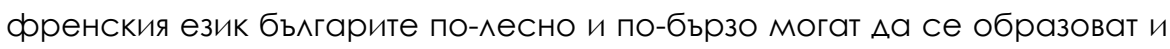
просветят тъй ката фрренската наука, изкуство и култура е много напреднала в сравнение с българската, която е изостанала. Речникът е полезен и за българите в Румъния за по-Аобро разбиране на румънския и на българския език. Авторьт сполеля, че при писането на речника са използвани чужАици, тъй като френския език е обработен, а българския не е обработен и е в процес на формиране на еАинен книжовен език. Призовава българите, ако забележат неправилно изтьлкувани Ауми Аа съобщят във вестника, за да стане речника съвьршен и за двата езика. В старопечатния библиотечен фонд се намират 6 учебника на Иван Богоров по българска граматика, география и френско-бьлгарски и българо-орренски речници:

Богоров, Иван А. - Всеобща географиия за децата, Белграл, Княжескосрьбска типографрия, 1843, 422 с.

Богоров, Иван А. - Първичка българска граматика, Букурещ, типографрия на СерА. К. Пенкович, 1844, 130 с. Този учебник е първата ни граматика, написана на народен новобългарски език. Тя е преиздалена три пъти като „Първичка българска словница".

Богоров, Иван А. - Кратка географиия математическа, фризическа и политическа, Букурещ, книгопечатня И. Копайниколов, 1851, 320 с.

Богоров, Иван А. - Упътване на българский язик, Виена, печ. На ^. Сомер, 1869, $16 \mathrm{C}$. 
Богоров, Иван А. - Българо-фрренски речник, Виена, книгопечатница на ^. Сомер, 1871, 506 с.

Богоров, Иван А. - Френско-български и българо-фрренски речник, Виена, книгопечатница на ^. Сомер, 1873, 516 с.

Училищният реорорматор Иван Момчилов е автор и съставител на реАица ценни учебници, и учебни пособия. В библиотечния фонн се пази колекция от 8 негови учебника: „Граматика за старобългарския йезик по сичкото му развитие" е пьрвата българска граматика по старобългарски език. Смята се за съвьршен учебник. Налага се с голяма известност, ползва се Аори и слеА ОсвобожАението.

Момчимов, Иван Н. - Граматика за старобългарския йезик по сичкото му развитие, Виена, типографрия на ^. Сомер, 1865, 247 с.

Момчилов, Иван Н. - Бележки връх граматиката на новобългарския език, Русчук, печ. на Аунавската област, 1868, 18 с.

Момчилов, Иван Н. - Свещен православен катихизис, Търново, Книгопродавница Момчилов и сие, 1869, 36 с. Начални книжки за Аецата в първоначалните ни народни училища. Книжка IV.

Момчилов, Иван Н. - Начален прочит, Търново, Книгопродавница на Момчилов и сие, 1869, 80 с. Начални книжки за Аецата в първоначалните ни народни училища. Книжка II.

Момчилов, Иван Н. - Малка аритметика, Търново, Книгопродавница на Момчилов и сие, 1869, 40 с. Начални книжки за децата в първоначалните ни народни училища. Книжка $\mathrm{V}$.

Момчилов, Иван Н. - Малко политическо земеописание, Търново, Книгопродавница на Момчилов и сие, 1869, 72 с. Начални книжки за цецата в първоначалните ни народни училища. Книжка IV.

Момчилов, Иван Н. - Свещен православен катихизис за народните ни училища, Търново, Книгопродавница Момчилов и сие, 1869, 56 с.

Момчимов, Иван Н. - Свещен православен катихизис за народните ни читалища, 2 (ново) изА., преработено и Аопьлнено с текстове от Св. писание, Търново, Книгопродавница Момчилов и сие, 1872, 66 с.

Теодор Хрулев е написал буквар, читанки и еАин от пьрвите учебници "Кратка математика". Във старопечатния фронА на библиотеката се намира учебник "Българска граматика" на ^ясковчанина Тодор Хрулев. В предисловието е описано важното 
значение на граматиката за изучаването на всички науки: „....якоя наука без Граматиката е като плет без полпорки, като кораб без кормило, или като кон без юзАа" (Khrulev, 1859: р. 4).

Хрулев, Теолор Т. - Българска граматика, Ръководство за българските юноши, Букурещ, типографрия на Йосифр Романов, 1859, 76 с.

А-р Васи^ Берон получава образованието си в чужбина и знае, „че всеки език е еАин прозорец към света и колкото повече езици знаеш, толкова повече се разширява културният ти кръгозор.

Знанието на чужАи езици е необходимо за развитието на политическите и тьрговските връзки межАу страните, за научното общуване. Той е полиглот: влалее арабски, гръцки, немски, руски, румънски, турски, фрренски. Затова и съставя през 1859 г. и издава в Букурещ "Първа българско-френска граматика с енно изложение за българското правописание." С този учебник Берон поставя началото на издаването на учебници по чуждоезиково обучение" (Vladeva, 2016: р. 249). През 1861 г. той отпечатва пьрвия български учебник по „Аогика” във Виена. В предисловието пише: „... най-необходима и можем да кажем найполезна за всеки, който се учи, трябва $А$ е оная наука, в която са изложени и разяснени законите на ума и разума" (Arshinkova, 1981: pp. 37-38). През 1865 г. в Болграл В. Берон написва и отпечатва пьрвия „Българо-фрренски буквар като приготовителна книжка на българскофрренската граматика". Посветен е на паметта на неговите дечица Стоенчо и Женда. Със загриженост и внимание към белните ученици Берон пише в предисловието: „Тоя буквар ще се $а$ ава в $а$ ар на всеки сиромах ученик от дето и $а$ б бъле, за което и всеки може своболно $\Delta а$ се отнесе Ао съчинителя му" (Beron, 1865: р. 7). В Болграл през 1868 г. изава "Пьрва българско-немска граматика". В предисловието се казва: „за $\Delta а$ се улесни нашата млалеж в изучаването и на Немския език полканих се, мили съотечественици, да съставя тая Бьлгаро-немска граматика. Главната Авигателна причина, която ме подбуди на това, е особено: Аа спомогна на единородците си, да могат по-скоро, и по ^есно Аа опознаят немския език; за $А$ а могат по такъв начин, $А$ а си обогатят познанията, и по различен начин, $а$ с се възползват, от найбогатата Писменост, във всичките почти отрасли на науките и на 
Изкуствата, на отличния тоя язик..." (Beron, 1868: р. 7). МеАикът Берон изаава в Болграл през 1870 г. пьрвия български научен труд по естествено-медицински науки и зъболечение „Естествена история пьрви пьт на български, систематически изложена с приложни забележки и практически изволи. Ч. І. Зоология. КАас І. Млекоподающи животни. Разрял І. Человек в сравнение с другите животни." Тези 5 пьрви български учебника на А-р Васил Берон са еАни от ценните съкровища на читалищната библиотека.

Берон, Васил х. Стоянов.- Първа българско-фрренска граматика с елно изложение за българското правописание, Букурещ, печ. Йосифо И.

Романов, 1859, 192 С.

Берон, Васил х. Стоянов. Аогика, първи път на български, Виена, печ на ^. Сомер, 1861, $212 \mathrm{C}$.

Берон, Васил х. Стоянов. Българо-орренски буквар като приготовителна книжка на българо-френската граматика, Болграл, Училищна книгопетница, 1865, 65 с.

Берон, Васил х. Стоянов. Първа българско-немска граматика, Болграл, печ. при Центр. учимище, 1868, 408 с.

Берон, Васил х. Стоянов. Естествена история първи път на български, систематически изложена с приложни забележки и практически изводи.

4. І. Зоология. КАас І. Млекоподающи животни. Разрял I. Человек в сравнение с Аругите животни. БолграА, печ. на Центр. учимище, 1870, 455 с.

Хр. Г. Аанов е автор на пет учебника: „Примери за краснописание“, „Кратка числителница за малки Аеца", "Пространна числителница с прибавени залавки за всяко Аействие", "Пространно священо битописание на цьрквата от вехтий и новий завет със 101 изображения. „Теоретическа и практическа числителница за ученици от средните класове и за самоуци". Във Въведението на "Пространна числителница" авторьт Аава следното определение:

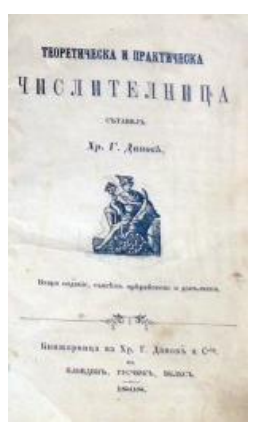
"Числителница е наука, която обяснява различните свойства на числата и показва ни прави^а, по които от няколко известни числа Аа можем Аа намираме Аруги неизвестни числа" (Danov, 1859: р. 1). От изАателя в 
читалищната сбирка се съхраняват 2 учебника по математика (числителница), отпечатани в чужбина.

Аанов, Хр. Г. Пространна числителница с прибавени заАавки за всяко Аействие, Пеща, книгопечатня Алоизия Бучянски, 1859, 189 с.

Аанов, Хр. Г. Теоретическа и практическа числителница за ученици от средните класове и за самоуци, 4 изл. Виена, печ. на Българското отлеление Янко С. Ковачев, 1874, 336 с.

Йоаким Груев превежла и написва учебници по различни предмети. „През 1869 г. започва разпространението на „Опитна фризика" от А. Гано. Този учебник се оказва труден за разбиране от учениците и това кара Груев $А$ направи нов превол на Аруг учебник по фоизика, този пьт от Шуберт 1872 г. Тук вече сьдьржанието е Аостьпно и онаглелено с чертежи и образи" (Lazarov, 2016: р. 228). Читалищната библиотека притежава 2 учебника на Йоаким Груев по история и по фоизика:

Груев, Йоаким, П. Начъртание на всеобща история за пьрвоначални училища, ново изАание, ПАовАив, Хр. Г. Аанов, 1867, 203 с.

Груев, Йоаким, п. Физика за главни народни училища, от А. Шуберт 1872 г. Прев..., ПАовАив, Хр. Г. Аанов, 1872, 192 с. с 76 оригури.

Кънчо Кесаров (Сахатчиолу) е автор на „Бьлгарска сметница" от 1859 г., "Читанка" 1869 г. и Аруги. В предисловието на „Българска сметница" научаваме, че мипсата на учебници по аритметика (сметница) е накарала учителя Кесаров Аа напише този учебник, така необхолим за обучението на учениците: „Сметницата ся счислява межАу пьрвите науки, защото ся зема тя за основа на математиката, ръководи художествата, и е главна управителка на търговските спекулации никой, а и най-изображения человек, не може $а$ изпьлнява никакво звание, ако не е учил и присвои^ знанията, които обема тази наука; с голямо прилежание еще в древните времена, и сега са намерва в съвършена степен и в голямо пространство. Можем Аа речем, че в нашето юношество не са е забележил Аосега голям успех в математическите науки, и на това не е причина оскунността на природните Аарби, а оскулността на книгите, които обемат тази наука, 
дето не са писани на български язик. Аритметиките, които се намерват напечатани на български язик твьрде са ограничени и не са в сьстояние Аа приготвят и улеснят учениците" (Kesarov, 1859: р. 1). Във фронАа на библиотеката се пазят 2 учебника - аритметика и читанка, написани от учителя Кьнчо Кесаров :

Кесаров, К. Българска сметница, ЦариграА - Галата, книгопечатница наА. Цанков и Б. Мирков, 1859, 297 с.

Кесаров, К. Читанка за народните училища, ЦариграА Печатницата на в. Македония 1869, 68 с.

Tодор Шишков като Аиректор на училищата в Търново 1869 г. съставя "Наръчен учебник на начална математика в три курса: аритметика, алгебра и геометрия за народните ни училища". Отпечатан е във Виена. През 1872 г. изАава „Начална българска граматика". През 1874 г. написва „Правилник или законник върху А^ъжностите на учителите. В старопечатната сбирка се съхранява еАин негов учебник по история:

Шишков, Т. Н. История на българския нарол, Цариграл, Царигралско читалище, 1873, 322 с.

нестор Марков е автор е на 7 учебници и речници по математика, физика, турски и френски езици. Счита се за елин от наймобрите лексикографри. За фрренско-българската ^ексикографрия е удостоен с почетно звание от Френската акалемия по изящни изкуства. Негов потомък е и продр. ст. н. с. І ст. А. М. н. Светослав Марков. СреА малкото учебници по математика в старопечатната сбирка се намира и пьрвият български сборник със залачи по аритметика, написан от Нестор Марков.

Марков, Нестор, К. - Събрани аритметични задатъци, Русчюк, печ. на Аунавската област, 1869, 192 с.

Аимитър Благоев написва „Изяснение на Букваря по „наглеАногласната метола" (как по него Аа преполават ролители и учители), 1874 г. Авторьт сполеля, че на детето му доскучава, още на втория урок, ако в буквара няма картинка. През 1875 г. е отпечатан „Буквар по нагледна и гласна метола" 1875 г. В старопечатната читалищна сбирка се съхранява 
възрожАенския буквар на Аимитьр Благоев от 1874 г. Този буквар се използва Аьлго време в българските училища и има наА 20 изАания.

Благоев, Аимитър - „Изяснение на Букваря по наглеАно-гласната метола" как по него Аа преподават родители и учители ПловАив, Русчук, Велес. Христо Г. Аанов, 1874, 18 с.

Христо Ваклидов е автор на „Буквар за орранцузкий язик” (18631865) и „Българско-фрранцузки и орранцузко-български речник" 1864 г. Преводач е 8 години от френски език в австрийското консулство в ОАрин (1864-1872). През 1858 г. превежла „Електрически телеграфр”, „Книжка за благонравието” 1858 г., „Благонравие за Аецата" 1875 г., „Начални алгебрически уроци” 1859 г., „Скитника евреин” 1860 г. и „Кратка свещена история" 1864 г. В старопечатния фонА на библиотеката се съхраняват „Електрически телеград”" и „Начални Алгебрически уроци", преведени от Христо Ваклидов и печатани с ижАивението на вилния търновец Пандели Кисимов. Учебник е ценен, той е пьрвият учебник по алгебра на български език.

ВаклиАов, Хр. Аочев - Електрически телеграфо, Цариграл - Галата, книгопечатница наА. Цанков и Б. Мирков, 1858, 168 с.

Ваклилов, Хр. Аочев - Начални Алгебрически уроци, Цариграл - Галата, книгопечатница наА. Цанков и Б. Мирков, 1859, 164 С.

Иван Гюзелев е автор на фоизико-математически трудове, фрилософрски съчинения и учебници. Наречен е „баща на българската фрилософрия". От Иван Гюзелев са запазени в старопечатния библиотечен фронА 2 учебника по геометрия и по фризика, Аоказали се във времето си. Учебникът по геометрия е преведен от руския профресор А. Аавидов и е съобразен много Аобре със спецификата на българските училища. Бил е най-Аобрият учебник по геометрия за времето си.

Гюзелев, Иван, Н. - Кратка елементарна геометрия с 177 чертежи в текста, Прага, книгопечатница на Гинск Милитки и Новак, 1873, 159 С.

Гюзелев, Иван, Н. - Ръководство Към фоизиката с 292 чертежа в текста, Прага, книгопечатница на Гинск Милитки и Новак, 1874, 458 с.

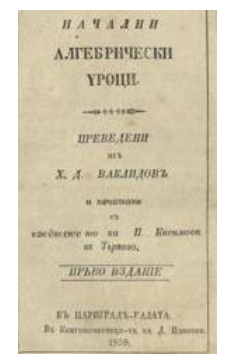


Учебниците са изАавани в различни Аьржави, тъй като по българските земи не е имало печатници. Най-много са отпечатвани в Цариграх в 7 печатници, тъй като там има^о голяма бъ^гарска колония. Алресите на другите печатници са в Белграл, Болграл, Букурещ, Виена, Крагуевац, Олеса, Прага, Пеща. Много от книгоизАателите са българи. От 60-голини на XIX век учебници се печатат и в ПловАив, Русе и Тьрново. Можем с пьлно право да кажем, че запазените пьрви учебници по български език, аритметика, алгебра, геометрия, фризика, географиия, история, естествена история, ^огика, нравоучение, фрренски и немски език и Аруги са книжовни реликви, съхранили Ауховната памет на Възраждането и времето на формиране на българската нация.

\section{ЗакАючение}

Всички автори на разглежАаните учебници са работили като учители. Парале^но с пелагогическата си дейност са намирали време, средства и начини да напишат, преведат и издалат учебната митература, за да ограмотяват и обучават българчетата.

Те са били еАни от най-образованите българи през XIX век, в^алеещи по няколко езика, превежАали са и книги. По-голямата част от тях са възпитаници на престижни училища и университети в Европа и Русия. Те вървят крачка напред пред времето си и водят българите към просветена, образована, цивилизована и културна Европа. Те стават пьрвите вестникари и журналисти и почват Аа списват пьрвите вестници и списания, пишат книги. Те са издатели и разпространители на книжовността. Те повежАат борбата за новобьлгарска просвета, еАинен книжовен новобългарски език, цьрковна независимост и политическа свобола. Те са народни будители защото будят народностното съзнание със слово и перо против Авойния гнет. Те са енциклопеАистите на Българското ВъзражАане Аонесли от Европа, не само знания и опит, но и свободния дух на страните, в които са учили и живели. Те редрормират образованието и на мястото на килийното, изгражАат светското. Те са новатори, въвеждат нови учебни Аисциплини, езици в крак с потребностите на новото време. Техните учебници се четат и от 
възрастните, които трябва $а$ а наваксат изпуснатите знания, за $\Delta а$ са пополезни за себе си и за отечеството. Те учреАяват читалища, Аружества, Археологическо Аружество. БКА: Членове на БКА (Анес БАН) са: Никола Михайловски, Иван Гюзелев, Сава Ралулов, Нестор Марков, Иван Богоров, А-р Васил Берон, Христо Г. Аанов.

Те са и дарители и спомоществователи. Преводачи са по време на Руско-турската война (1877-1878). СлеА Освобожлението те пак са на преАни позиции, защото са строителите на Третата Българска Аьржава. Тя възкръсва на 16 април преди 140 години с полписването на Търновската конституция, и слеА 5 века забрава България грейва на картата на Европа. И като най-образовани, тези Аостойни АюАе са алминистратори и дьржавници: кметове, предселатели, сьлии, министри, народни преАставители.

Аепутати в Учредителното и І Велико народно събрание 1879 г. са Никола Михайловски и Иван Гюзелев, който е Аепутат и във II ВНС, І ОНС, II ОНС. Христо Г. Аанов е Аепутат в Областното събрание на Източна Румелия 1882 г. Нестор Марков е Аепутат в III ВНС, (1886-1887) и в XII OHC. Анес с това изложение, казано метафрорично, ще се изтупа праха от учебниците: буквари, читанки, граматики, сметници, числителници, речници и Ар. Но нека се изтупа и праха на забвението от миковете на даскали и учебникари, някои известни, Аруги понеизвестни, възродили българското име и племе от нерадостната ни

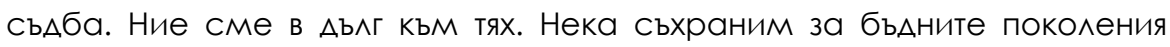
завещаните ни Ауховни съкровища и успеем Аа ги Аигитализираме.

\section{AUTEPATYPA / REFERENCES}

Arshinkova, S. (1981). Doctor Vasil Hadjistianov Beron (1300 years Bulgarian state). In: Journal of Problems of Higher Education, S., 1981, № 4, 37-38. (In Bulgarian) / [С. Аршинкова, Аоктор Васил ХаАжистоянов Берон (1300 голини българска Аьржава). В: Списание Проблеми на висшето образование, С., 1981, № 4, 37-38.]

Beron, V. x. Stoyanov, (1865). The Bulgarian-French Literary Book as a Preparation Book of the Bulgarian-French Grammar, Bolgrad, School Bookbinder, 1865, 7. (In Bulgarian) / [B. х. Стоянов Берон, Българо-фрренски буквар като приготовителна книжка на българо-фрренската граматика, БолграА, Училищна книгопетница, 1865, 7.] 
Beron, V. x. Stoyanov, (1868). First Bulgarian-German Grammar, Bolgrad, Center Cave. school, 1868.7. (In Bulgarian) / [В. х. Стоянов Берон, Пьрва българсконемска граматика, Болграл, печ. при Центр. училище, 1868,7.]

Danov, Hr. G. (1859). Spatial numerator with added throttles for each action, Furnace, Aloysius Buchansky, 1859, 1 (In Bulgarian) / [Хр. Г. Аанов, Пространна числителница с прибавени залавки за всяко Аействие, Пеща, книгопечатня Алоизия Бучянски, 1859, 1.]

Draganova, D.; Dimitrov, D. (1982). Educational and cultural development of Tarnovo in the 19th century. In : Veliko Tarnovo of the centuries. S., 1982, 213 (In Bulgarian) / [Просветно и културно развитие на Търново през XIX век. В: Сборник Велико Търново през вековете.С., 1982, 213.]

Kesarov, K. (1859). Bulgarian Garbage Store, Constantinopole - Galata, bookstore by D. Tzankov and B. Mirkov, 1859, 1. (In Bulgarian) / [K. Кесаров, Българска сметница, ЦариграА-Галата, книгопечатница на А. Цанков и Б. Мирков, $1859,1$.

Khrulev, T. (1859). Bulgarian Grammar, Guide for Bulgarian Adolescents, Bucharest, Typography of Joseph Romanov, 1859, 4 (In Bulgarian) / [Т. Хрулев, Българска граматика, Ръководство за българските юноши, Букурещ, типографрия на Йосифо Романов, 1859, 4.]

Lazarov, V. (2016). National Revival Textbooks from the 20 s to the 70 s of the Nineteenth Century, kept in the National Museum of Education. In: Proceedings from Regional to National - Educational Affairs and Museums, VT, 2016, (In Bulgarian) / [В. Аазаров, Възрожленските учебници от 20-те Ао 70-те години на XIX век, съхранявани в Национален музей на образованието. В: Сборник От регионалното към националното - Просветното Аело и музеите, В. Т., 2016, 222.]

Panayotova, K.; Bachvarova, N. (2009). History of the Nadezhda 1869 Community Center in Veliko Tarnovo. VT, 2009, 15 (In Bulgarian) / [К.Панайотова, Н. Бъчварова, История на читалище „Належла 1869" Велико Търново. В. Т., $2009,15$.

Vladeva, P. (2010). Members of Parliament from the Tarnovo Province at the Constituent Assembly of 1879. In: Proceedings From the Regional to the National - Numismatics, Sphragistics, Epigraphy and Museum. VT, 2010, (In Bulgarian) / [П. В^алева, Народни представители от Търновска губерния в Учредителното събрание от 1879 г. В: Сборник От регионалното към националното - нумизматика, соррагистика, епиграфрика и музейно Аело. B.T., 2010, 399.]

Vladeva, P. (2016). Life dedicate to the Bulgarian cause. In: Proceedings From Regional to National - Educational Affairs and Museums, VT, 2016, (In Bulgarian) / [П. Влалева, Живот отАален на българската кауза. В: Сборник

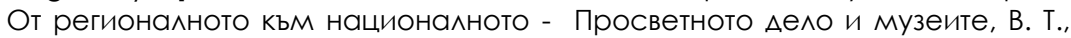
2016, 249.]

Yankov, T. (1939). Travelogues. Book I. S., 1939, 139 (In Bulgarian) / [T. ЯНКов, Пьтеписи. Книга І. С., 1939, 139. 


\section{ПРИАОЖЕНИЕ 1.}

\section{Списък на възрожАенски учебници от старопечатната сбирка на библиотеката при читалище „НаАежАа-1869” / List of revival textbooks from the old print collection of the library at the community center "Nadezhda-1869" \\ Всички изображения в този текст са от списъка по-Аолу}

1. Рилски, Неофрит - Болгарская граматика, Крагуевац, Княжеско-сербска типография, 1835, $211 \mathrm{c.}$

2. ВаскиАОвич, Емануи^ - Аетинско притавление или различни нравствени поучения и нравоучителни истории, ЦариграА, типографрия Ц. Вестник, $1852,136 \mathrm{C}$.

3. Сичан-Николов, Христолул Костович - Граматика или буквеница словенска, Цариграл - Галата, книгопечатница на А. Цанков и Б. Мирков, 1858, 168 с.

4. Ралулов, Сава - Учебник за българский язык, преведен е преработен от полобен русский учебник", Болграл, печатница на Българското централно училище, 1863, 150 с.

5. Ралулов, Сава - Българский буквар, Олеса,типографрия на П.Францова, 1866,32 с.

6. Ралулов, Сава - Начална граматика за изучения на българский язик. Книжка І, Болграл, печатница на Централно училище, 1870, 116 с.

7. Ралулов, Сава - Нравоучение за децата (от Аьо Пренс Аьомон) (превол) 3 изА., БолграА, печатница Централно училище, 1871, 150 с.

8. Ралулов, Сава - Начална граматика за изучение на българский язик по начин практически. Книжка І, 2 изА., Болграл, печатница Централно училище, $1873,119 \mathrm{C}$.

9. Михайловски, Никола, С. - Очерки из историята и народните сказания (Аревняя история). Виена, типография на ^. Сомер, 1865, 367 с.

10. Михайловски, Никола, С. - Малка българска читанка, Виена, печ. на . Сомер, 1866, $70 \mathrm{c}$.

11. Михай^овски, Никола, С. - Мальк български писмовник или образци за различни писма, Русчук, печ. на Аунавската област, 1868, 64 с.

12. Михайловски, Никола, С. - Ръководство към всеобщата история. Състави^А. И^овайский, Прев. Търново, Книгопродавница Момчи^ов и сие, 1873, 338 с.

13. Богоров, Иван А. - Всеобща географиия за децата, Белграл, Княжеско-срьбска типография, 1843, 422 с.

14. Богоров, Иван А. - Пьрвичка българска граматика, Букурещ, типографрия на СерА. К. Пенкович, 1844,130 с.

15. Богоров, Иван А. - Кратка географиия математическа, фризическа и политическа, Букурещ, книгопечатня И. Копайниколов, 1851, 320 с.

16. Богоров, Иван А. - Упьтване на българский язик, Виена, печ. На ^. Сомер, 1869, 16 с. 
17. Богоров, Иван А. - Българо-орренски речник, Виена, книгопечатница на $А$. Сомер, 1871, $506 \mathrm{C}$.

18. Богоров, Иван А. - Френско-български и българо-фрренски речник, Виена, книгопечатница на А. Сомер, 1873, 516 с.

19. Момчилов, Иван Н. - Граматика за старобългарския йезик по сичкото му развитие, Виена, типография на ^. Сомер, 1865, 247 с.

20. Момчилов, Иван Н. - Бележки връх граматиката на новобългарския език, Русчук, печ. на Аунавската област, 1868, 18 с.

21. Момчилов, Иван Н. - Свещен православен катихизис, Търново, Книгопродавница Момчилов и сие, 1869, 36 с. Начални книжки за децата в пьрвоначалните ни народни училища. Книжка IV.

22. Момчилов, Иван Н. - Начален прочит, Търново, Книгопродавница на Момчилов и сие, 1869, 80 с. Начални книжки за децата в пьрвоначалните ни народни училища. Книжка II.

23. Момчи^ов, Иван Н. - Малка аритметика, Търново, Книгопродавница на Момчилов и сие, 1869, 40 с. Начални книжки за децата в първоначалните ни нароАни учиАища. Книжка $\mathrm{V}$.

24. Момчилов, Иван Н. - Малко политическо земеописание, Търново, Книгопродавница на Момчилов и сие, 1869, 72 с. Начални книжки за Аецата в пьрвоначалните ни народни училища. Книжка IV.

25. Момчи^ов, Иван Н. - Свещен православен катихизис за народните ни училища, Търново, Книгопродавница Момчилов и сие, 1869, 56 с.

26. Момчилов, Иван Н. - Свещен православен катихизис за народните ни читалища, 2 (ново) изА., преработено и Аопьлнено с текстове от Св. писание, Търново, Книгопродавница Момчи^ов и сие, 1872, 66 с.

27. Хрулев, Теолор Т. - Българска граматика, Ръководство за българските юноши, Букурещ, типография на Йосифр Романов, 1859, 76 с.

28. Берон, Васил х. Стоянов - Пьрва българско-орренска граматика с елно изложение за българското правописание, Букурещ, печ. Йосифр И. Романов, 1859, 192 с.

29. Берон, Васил х. Стоянов - ^огика, пьрви пьт на български, Виена, печ на $\wedge$. Сомер, 1861, $212 \mathrm{c}$.

30. Берон, Васил х. Стоянов - Българо-орренски буквар като приготовителна книжка на българо-фрренската граматика, Болграл, Училищна книгопетница, 1865, 65 c.

31. Берон, Васил х. Стоянов - Пьрва българско-немска граматика, Болграл, печ. при Центр. училище, 1868, 408 с.

32. Берон, Васи^ х. Стоянов - Естествена история пьрви пьт на български, систематически изложена с приложни забележки и практически извоАи. Ч. І. Зоология. К^ас І. М^екоподающи животни. Разрял І . Человек в сравнение с Аругите животни. БолграА, печ. на Центр. училище, 1870, 455 с.

33. Аанов, Хр. Г. - Пространна числителница с прибавени залавки за всяко Аействие, Пеща, книгопечатня Алоизия Бучянски, 1859, 189 с. 
34. Аанов, Хр. Г. - Теоретическа и практическа числителница за ученици от среАните класове и за самоуци, 4 изА. Виена, печ. на Българското отлеление Янко С. Ковачев, 1874, 336 с.

35. Груев, Йоаким, П. - Начъртание на всеобща история за пьрвоначални училища, ново изАание, ПловАив, Хр. Г. Аанов, 1867, 203 с.

36. Груев, Йоаким, П. - Физика за главни народни учи^ища, от А. Шуберт 1872 г. Прев, ПловАив, Хр. Г. Аанов, 1872, 192 с. с 76 фригури.

37. Кесаров, К. - Българска сметница, ЦариграА - Галата, книгопечатница на А. Цанков и Б. Мирков, 1859, 297 с.

38. Кесаров, К. - Читанка за народните училища, Цариграл Печатницата на в. Македония 1869, $68 \mathrm{C}$.

39. Шишков, Т. Н. - История на българския народ, Цариграл, Царигралско читалище, 1873, 322 с.

40. Марков, Нестор, К. - Събрани аритметични задатъци, Русчюк, печ. на Аунавската област, 1869, 192 с.

41. Благоев, Аимитьр - „Изяснение на Букваря по нагледно-гласната мето $а " ~$ по него да преподават родители и учители Пловлив, Русчук, Велес. Христо Г., 1874, $18 \mathrm{C}$.

42. ВаклиАов, Хр. Аочев - Електрически телеграф, Цариграл - Галата, книгопечатница на А. Цанков и Б. Мирков, 1858, 168 с.

43. Вак^иАОв, Хр. Аочев - Начални Алгебрически уроци, Цариграл - Галата, книгопечатница на А. Цанков и Б. Мирков, 1859, 164 с.

44. Гюзелев, Иван, Н. - Кратка елементарна геометрия с 177 чертежи в текста, Прага, книгопечатница на Гинск Милитки и Новак, 1873, 159 с.

45. Гюзелев, Иван, Н. - Ръководство към фризиката с 292 чертежа в текста, Прага, книгопечатница на Гинск Милитки и Новак, 1874, 458 с. 


\section{КУАТУРНО-ИСТОРИЧЕСКО НАСАЕАСТВО: \\ ОПАЗВАНЕ, ПРЕАСТАВЯНЕ, АИГИТААИЗАЦИЯ}

CULTURAL AND HISTORICAL HERITAGE

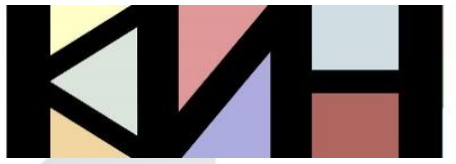

PRESERVATION PRESENTATION DIGITIZATION
Материалите в сборника са обект на авторско право. Разрешава се безвьзмезАното ползване на техни електронни/ хартиени копия само за лична употреба или обучение, при пьлно

цитиране на текущата страница и слеА писмена дек^арация от цитиращия за липса на тьрговски намерения.

За копиране пол Аруга фоорма, препубликуване или публикуване на сьрвьри се изисква писмено разрешение и/или зап^ащане.

(С) Авторски колектив, 2019

Технически реАактори:

Николай Ноев

Калина Сотирова-Вьлкова

Ка^оян Николов

\section{Editors}

Galina Bogdanova

Vanya Mateeva

This work is subject to copyright.

Open and free of charge use of digital/hard copies of publications is granted only for personal or educational use, with full citation of the current page, and after written declaration of the quoting side for not-commercial Intention. For any other reproducing types, re-publishing, photocopying, recording, or any other storage retrieval system/ server written permission and/or fee is required.

(C) Authors` Group, 2019

Technical editors:

Nikolay Noev

Kalina Sotirova-Valkova

Kaloyan Nikolov

Научна поредица: том 5, брой 2 (7)/2019

Science series: vol. 5 , issue 2 (7)/2019

www.math.bas.bg/vt/kin

ISSN: 2367-8038 